\title{
Experimental Study on Partial Replacement of Cement with Mineral Admixtures and Sand with Quarry Dust \\ Fatheali A Shilar ${ }^{1}$, Mubarakali Shilar ${ }^{2}$ \\ ${ }^{1}$ School of Civil and Environmental Engineering, KLE-Technological University, Vidyanagar, Hubballi-580030, Karnataka, India. \\ ${ }^{2}$ Department of Mechanical Engineering, Gogte Institute of technology, Belagavi-580001, Karnataka, India
}

ABSTRACT: This paper focuses on utilization of mineral admixture in the partial replacement of cement; attempt has been made to enhance the properties of concrete. The admixtures are used in general where the mineral admixtures fly ash and micro silica are quiet commonly used in achieving higher compressive strength. This mineral admixture reacts with cement which further increases the strength of concrete. These admixtures and superplasticizers play primary role in the manufacturing of high strength concrete. To enhance the properties of concrete, the admixtures are used in general where the mineral admixtures fly ash and micro silica are quiet commonly used in achieving higher compressive strength. These admixtures and superplasticizers play primary role in manufacturing the high strength concrete. This mineral admixture reacts with cement which further increases the strength of concrete. The optimum mix design using four different mixes proportions of concrete are prepared using cement, fine aggregates, coarse aggregates, micro silica, fly ash and quarry dust on which the experimental study was carried out.

KEYWORDS: Cement, Fly Ash, Silica, Quarry Dust, Compressive Strength, Water Absorption, Split Tensile Tests.

\section{INTRODUCTION}

Concrete, one of the widely used material in the construction sector which is composed of the binding material-cement, the filler material-fine aggregates and coarse aggregates, water for hydration of binding material and sometimes admixtures to enhance the property of the concrete. The concrete having compressive strength more than $40 \mathrm{Mpa}$ for 28 days is termed as high strength concrete. Usually in India high strength concrete is used for pre stressed concrete bridges. The water cement ratio of high strength concrete is taken as in the range of 0.35 to 0.40 or even lower. To achieve maximum water decrease in high strength concrete use high range water reducers [1].

Fly ash which is well-called as pulverized fuel ash which is mechanically or electro-statically precipitated ash of coal fired power stations exhaust gases. This waste ash is another pozzolana material which is beneficial in this aspect but this is not as effective as the silica fumes. In the production of cement the fly ash is used. It is likewise utilized as a filling material in dams, as a sub base and base material in parkway developments, in holding dividers and furthermore as light weight development material. The pozzolanic properties and filler property of fly slag upgrade the attributes of the two mortars and cement like other pozzolana material. As fly ash is the less used by product of coal fired power stations its availability is at very low cost than the silica fumes which encourages its utilization from the economical aspect [2].

Miniaturized scale silica or silica rage is another pozzolanic material acquired in the creation of silicon and ferrosilicon combination which comprises of ultrafine molecule of normal distance across 150 nanometer. The tests on the utilization of smaller scale silica in cement is begun long in 1952 due to pozzolanic normal for material which helps in accomplishing high quality and tough cement by supplanting bond with miniaturized scale silica [2].

In stone quarries while during the time spent pulverizing the stones in smasher units, squander material or residue is richly kept known as quarry dust which can be successfully utilized as a substitution to regular fine total in solid creation. Prior examination demonstrates that stone smasher dust has a decent potential as fine total in solid development. The quarry dust which by and large alluded as waste item helps in lessening the expense of building and furthermore decreased effect on condition. Smasher dust has potential as fine total in solid structure with a decrease in expense of cement by around 20 percent contrasted with customary cement $[3,4]$.

Concrete engineering and technology is one of the waste areas for research and over the years, tremendous research have been carried in studying the incorporation of by products and waste materials in the preparation of concrete. Ozkan Sengul [5] studied the effect of use of finely powered fly ash and finely powered granulated blast furnace slag as alternative to cement in concrete. In this study he prepared concrete by using alternative to cement by half of fly ash, half of blast furnace slag and with quarter of fly and blast furnace slag at two water/binder ratios of 0.60 and 0.38 The compressive strength of concrete prepared using ordinary Portland cement is more than that of concretes prepared by partial replacing cement with pozzolana at higher water/binder ratio. And the reduction in strength is more in high water/binder 
content than of lower water/binder content. And he observed the maximum strength when cement is replaced with half of slag. The higher strength and improved electric resistance is seen at $6 \%$ micro silica and $1.5 \%$ silica replacement to the cement. Silica fume is a material which may be a reason of Air Pollution this is a byproduct of some Industries use of microsilica with concrete decrease the air pollution. Silica fume also decrease the voids in concrete. Addition of silica fume reduces capillary. Absorption and porosity because fine particles of silica fume reacts with lime present in cement [6].

Dehwaah [7] investigated the cement mortars that are prepared by alternative to natural river sand fine aggregate by quarry dust by varying proportion of cement and quarry dust. At 0.60 ratio of fine to aggregates, the quarry dust found to enhance elastic modulus and compressive strength of test specimens. Joseph et al [8] studied the performance of concrete that are prepared by replacing conventional river sand and fine aggregates by quarry dust and lateritic sand. The three mixes 1:1:2, 1:1.5:3 and 1:2:4 are prepared by varying the quantity of lateritic at $0 \%$ to $100 \%$ against interval of $25 \%$ quarry dust, which are water cured and tested for compressive strength. The higher compressive strength is seen at 0.50 water/binder content of 1:1:2 mix. In case of concrete containing not more than $50 \%$ lateritic can be used as structural member.

Mehmete Gesogalu et al [9] investigated the properties of the high strength concrete prepared by alternative to sand by quarry dust. Mix design is carried out with and without use of rice husk ash for 60 $\mathrm{MPa}$ and $70 \mathrm{MPa}$ concrete and cured for 28 days by water curing and for the mix prepared with rice husk ash; the fine aggregate is partial replaced with quarry dust at $10 \%$ to $40 \%$

The slump test for fresh concrete have been carried out to check the workability and test on compressive strength are carried out at the end of 28 days of water curing. The concrete that is prepared with $20 \%$ quarry dust as replacement obtained as the optimum mix design for both $60 \mathrm{Mpa}$ and $70 \mathrm{Mpa}$ grade of concrete. But decrease in compressive strength is seen in concrete at later stages incorporating quarry dust replacement for sand.

The main objective of the present work is to study the behaviour of high strength concrete by partial replacement of ordinary cement with mineral admixtures and fine aggregate with quarry dust. To determine the Compressive strength, Split/Indirect tensile strength and water absorption for concrete mix. In addition to calculate the optimum dosage of micro silica, fly ash and quarry dust as replacement material to attain the highest compressive strength of concrete. Finally, the durability of concrete by Alkalinity test of concrete to suitability of concrete was studied.

\section{MATERIALS AND METHODS}

\subsection{Cement}

The cement is obtained from Munvalli traders, Gadag and the brand of cement used in present study is Ultra tech ordinary Portland cement of 43 grade conforming to IS: 8112-1989. The most important component of cement is tri-calcium silicate and dicalcium silicate this is responsible for strength.

Table 1 Testson Cement

\begin{tabular}{|c|c|}
\hline Name of the Test & Results Obtained \\
\hline $\begin{array}{c}\text { Specific gravity of } \\
\text { Cement }\end{array}$ & 3.12 \\
\hline $\begin{array}{c}\text { Fineness test on } \\
\text { cement }\end{array}$ & $6.33 \%$ \\
\hline
\end{tabular}

\subsection{Fly ash}

Fly ash of Class F is used in the present study. The finely powered ash residue that obtained as the result of combustion of coal is known as fly ash. The fly ash is obtained from Suresh Enterprises Pvt. Ltd.

Table 2 Tests on Fly Ash

\begin{tabular}{|c|c|c|}
\hline Name of the test & $\begin{array}{c}\text { Results } \\
\text { obtained }\end{array}$ & $\begin{array}{c}\text { IS } \\
\text { Specifications }\end{array}$ \\
\hline $\begin{array}{c}\text { Specific gravity } \\
\text { of Fly ash }\end{array}$ & 2.13 & $2-6$ \\
\hline $\begin{array}{c}\text { Fineness test on } \\
\text { Fly ash }\end{array}$ & $8 \%$ & $10 \%$ maximum \\
\hline
\end{tabular}

\subsection{Micro Silica}

Silica fume also called as micro silica is a residue obtained from ferro-silicon metals industry. Ferrosilicon metals are created in electric heaters for sealants, and different items. The emanations from the heater are gathered. Silica rage particles are $1 / 100^{\text {th }}$ the size of concrete. Micro silica is obtained from Sai Dhurga Enterprises at Bangalore.

Table 3 Test on Micro Silica

\begin{tabular}{|c|c|}
\hline Name of the test & Results obtained \\
\hline $\begin{array}{c}\text { Specific gravity of } \\
\text { Microsilica }\end{array}$ & 2.16 \\
\hline
\end{tabular}

\subsection{Fine Aggregate}

Naturally occurring sand obtained from Local River was used as filler fine aggregate. Advantage of natural sand is that gives good workability. The fine aggregate is obtained from Suresh Enterprises Pvt. Ltd

Table 4 Tests on Fine Aggregate

\begin{tabular}{|c|c|c|}
\hline Name of the test & $\begin{array}{c}\text { Results } \\
\text { obtained }\end{array}$ & $\begin{array}{c}\text { IS } \\
\text { Specifications }\end{array}$ \\
\hline $\begin{array}{c}\text { Specific gravity of } \\
\text { Fine Aggregate }\end{array}$ & 2.73 & $2-6$ \\
\hline $\begin{array}{c}\text { Fineness Modulus } \\
\text { of fine Aggregate }\end{array}$ & Zone II & IS 383-1970 \\
\hline
\end{tabular}

\subsection{Quarry Dust}

Quarry dust is obtained from stone quarries as waste material while crushing stones, stone crusher dust, which is available abundantly from crusher units. For the present study, Quarry dust is obtained from Suresh Enterprises Pvt. Ltd Crusher unit Shitalahari Taluk: Shirrati, Dist: Gadag. 
Table 5 Tests on Quarry Dust

\begin{tabular}{|c|c|c|}
\hline Name of the test & $\begin{array}{c}\text { Results } \\
\text { obtained }\end{array}$ & $\begin{array}{c}\text { IS } \\
\text { Specifications }\end{array}$ \\
\hline $\begin{array}{c}\text { Specific gravity of } \\
\text { Quarry Dust }\end{array}$ & 2.16 & $2-6$ \\
\hline $\begin{array}{c}\text { Fineness Modulus } \\
\text { of Quarry Dust }\end{array}$ & Zone II & IS 383-1970 \\
\hline
\end{tabular}

\subsection{Coarse Aggregate}

The least porous and strongest material in concrete composition is coarse aggregate. It reduces drying shrinkage and other dimensional changes due to moisture. To achieve maximum compressive strength with high binder and at low water cement ratio, size of coarse aggregate play an important role. The fine aggregate is obtained from Suresh Enterprises Pvt. Ltd.

\section{Table 6 Tests on Coarse Aggregates}

\begin{tabular}{|c|c|}
\hline Name of the test & $\begin{array}{c}\text { Results } \\
\text { obtained }\end{array}$ \\
\hline $\begin{array}{c}\text { Specific gravity of } \\
\text { Coarse Aggregate }\end{array}$ & 2.74 \\
\hline $\begin{array}{c}\text { Aggregate Crushing } \\
\text { Value }\end{array}$ & $21.93 \%$ \\
\hline $\begin{array}{c}\text { Aggregate Impact } \\
\text { Value }\end{array}$ & $36.23 \%$ \\
\hline
\end{tabular}

\section{METHODOLOGY}

The following mixes are prepared for current study: Mix 1(M1): Conventional Concrete with ordinary Portland cement, river sand as fine aggregates and 20 mm down size gravel as coarse aggregates.

Mix 2 (M2): Concrete of high strength with ordinary Portland cement, 5\% fly ash and 5\%micro silica as alternative for cement, $5 \%$ quarry dust as alternative for fine aggregates and $20 \mathrm{~mm}$ down size gravel as coarse aggregates.

Mix 3 (M3): Concrete of high strength with ordinary Portland cement, $10 \%$ fly ash and $10 \%$ micro silica as alternative for cement, $10 \%$ quarry dust as alternative for fine aggregates and $20 \mathrm{~mm}$ down size gravel as coarse aggregates.

Mix 4 (M4): Concrete of high strength with ordinary Portland cement, $15 \%$ fly ash and $15 \%$ micro silica as alternative for cement, $15 \%$ quarry dust as alternative for fine aggregates and $20 \mathrm{~mm}$ down size gravel as coarse aggregates.

\subsection{Preparation of Test Specimens}

The test examples were threw in cast-press steel molds. Furthermore, oil is connected for the inside bit of the form for simple demoulding. The fixings were burdened a computerized parity and put in container blender machine for blending in dry condition. It was guaranteed that a uniform shade of the blend was gotten before including water. Water is included for right amount utilizing estimating container. Proportioning of a solid blend implies deciding the general measures of materials (bond, total, water) required for groups of cement for required quality. The examination was completed with standard blend M30 with water/concrete proportion 0.40 . This is done to know the potential outcomes of consideration of small scale silica in ideal extent in the normal development exercises utilizing bond concrete.

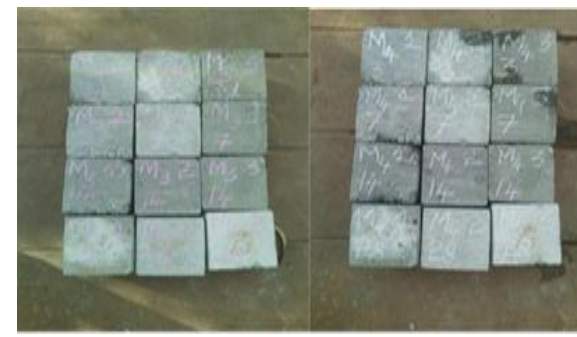

Figure 1 Cubes of concrete

\subsection{Tests on Concrete \\ 3.2.1 Slump Cone Test}

The apparatus required to test a slump should be in the form of cone of metallic mould having internal dimensions of cone as: Bottom diameter of $200 \mathrm{~mm}$, Top diameter of $100 \mathrm{~mm}$ and Height of $300 \mathrm{~mm}$. [9]

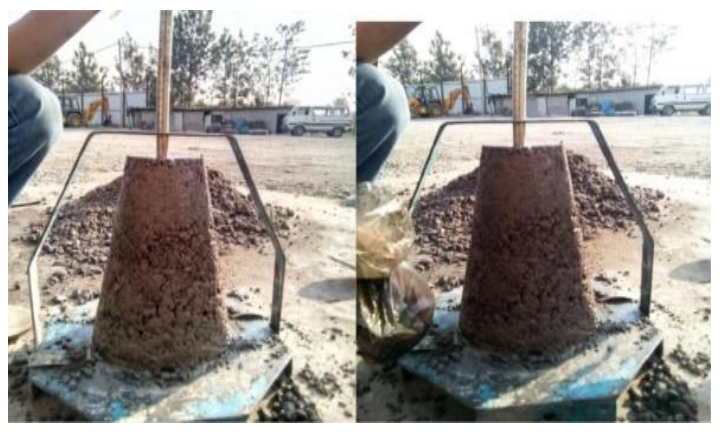

Fig 2 Slump tests

\subsubsection{Compressive Strength Test}

The test specimens which are cured in water are removed from stored water tank and should test immediately. After removing test specimen from water the specimens should be wiped with clean cloth to ensure no wet condition surface on specimen and also projecting fines should be wiped off. The compressive strength test is conducted as follows using compression testing machine. The average reading is final compressive strength of the test specimen [10].

Compressive strength $=(\mathrm{P} / \mathrm{A}) \times 1000$

Where $\mathrm{P}=$ load in $\mathrm{KN}, \mathrm{A}=$ Area of cube surface in $\mathrm{mm}^{2}$

\subsubsection{Split Tensile Strength Test}

The test specimens which are cured in water are removed from stored water tank and should test immediately. After removing test specimen from water the specimens should be wiped with clean cloth to ensure no wet condition surface on specimen and also projecting fines should be wiped off. The split tensile strength test is conducted as follows using compression testing machine [11].

Split tensile strength $=(2 \mathrm{P} /(22 / 7 \mathrm{dl}))$

Where $\mathrm{P}=$ load in $\mathrm{KN}, \mathrm{D}=$ diameter of cylinder, $\mathrm{L}=$ length of cylinder 


\subsubsection{Water Absorption Test}

The water absorption for test specimen is conducted as per procedure of oven-drying method. For this test $150 \mathrm{~mm} \times 150 \mathrm{~mm} \times 150 \mathrm{~mm}$ cubes and $150 \mathrm{~mm} \times 300 \mathrm{~mm}$ cylinder are casted. The test specimens are removed after 24 hours from mould and kept in water tank for curing. At the end of 3, 7, 14 and 28 days the specimens are taken out from the water tank and air dried to remove the surface moisture then take the initial weight as (W1). And the specimens are kept in oven with constant temperature of 100 to 110 oc for 24 hours. And after removing from oven the specimens are left to cool at room temperature and take the final weight as (W2). Finally calculate the water absorption by using the formula [11].

$\%$ of water absorption $=\frac{\left(w_{1}-w_{2}\right)}{w_{2}}$

\subsubsection{Alkalinity Test}

Alkalinity test is carried out by using phenolphthalein indicator. First the concrete cubes or cylinders are tested in a compression testing machine and taken out from the machine. At that point 2 to 3 drops of Phenolphthalein pointer are showered on the part of solid surface where it comes up short. The adjustment in shading in that part of cement shows the measure of alkalinity [12].

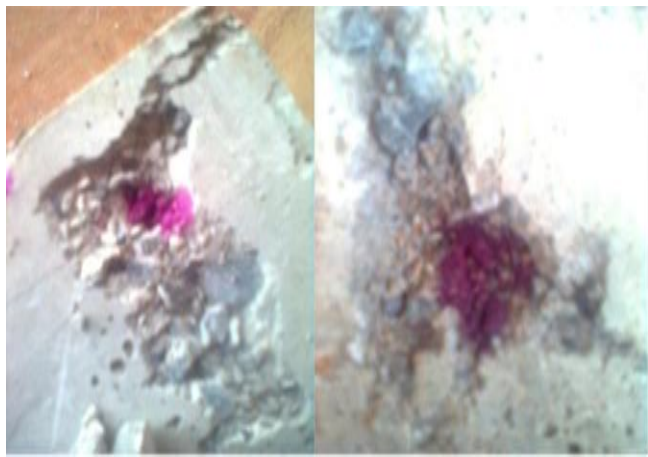

Fig 4.4 Alkalinity of Mix 1 and Mix 2

\section{RESULTS AND DISCUSSION 4.1 Slump Cone Test}

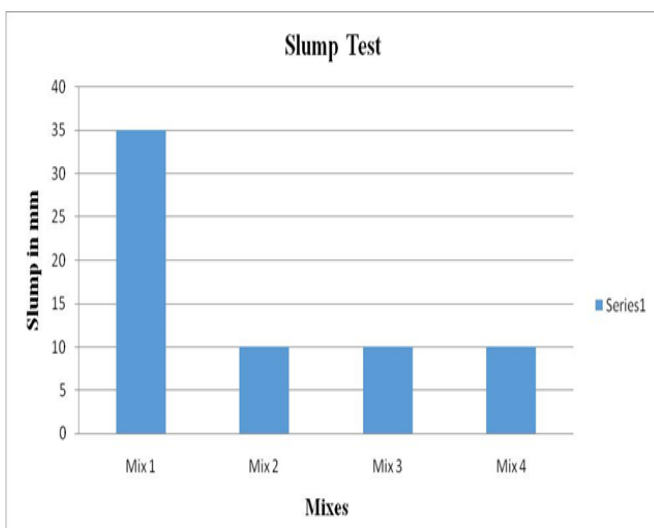

The slump value for mix -1 is higher than mix-2, mix-3 and mix-4, 1. Adding of mineral admixtures (micro silica and fly ash) to the concrete decreases slump value which leads low workability.

\subsection{Compressive Strength Test}

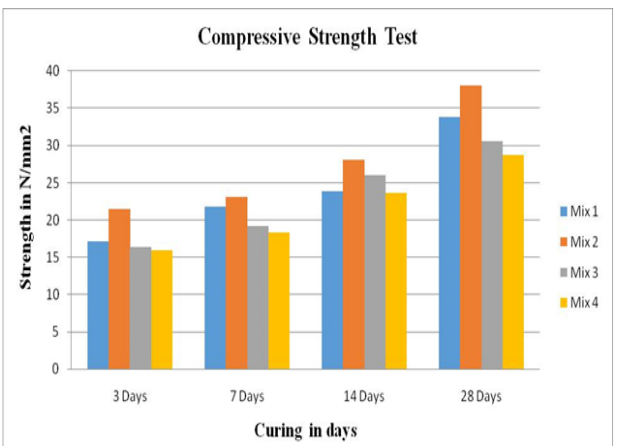

The percentage increase of compressive strength from mix 1 to mix 4, so compressive strength for mix2 is higher than other mixes.

\subsection{Water Absorption Test}

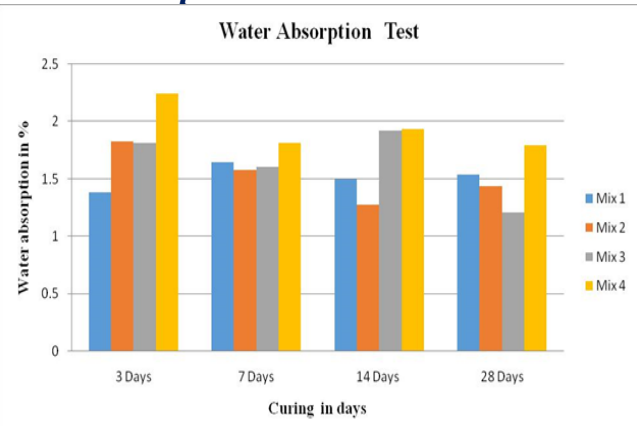

Water absorption for mix-4 is higher than other mixes for $3,7,14 \& 28$ days

\subsection{Split Tensile Test}

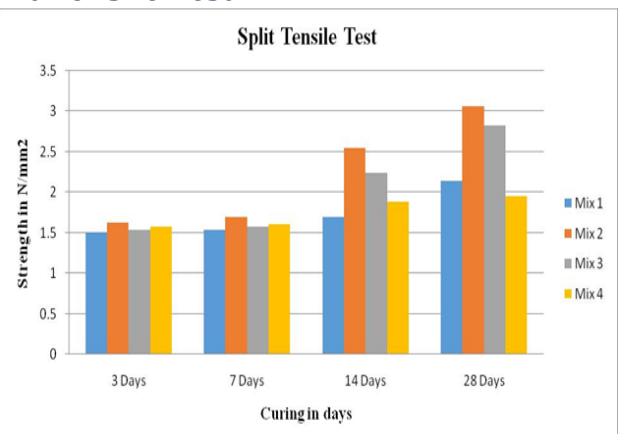

Split tensile test for concrete for mix-2 is higher then other mixes, at 28days and mix- 4 is lower at 28 days

\subsection{Density of Cubes}

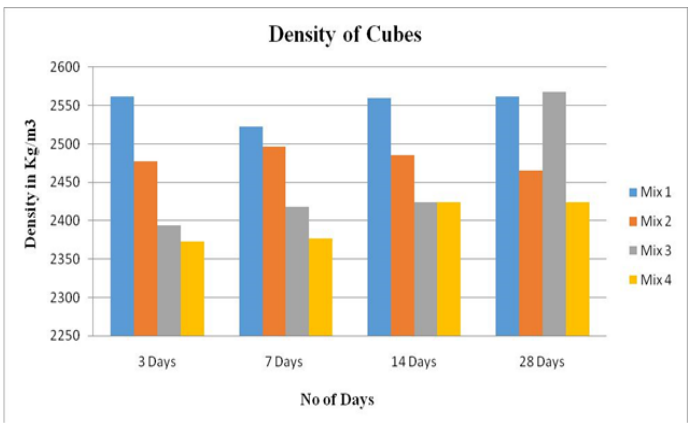


The density of concrete is decreased by addition of micro silica, quarry dust and fly ash to the concrete. This results in the production of light weight concrete.

\subsection{Alkalinity Test}

Table 6 Alkalinity Test

\begin{tabular}{|c|c|c|}
\hline $\begin{array}{c}\text { Concrete } \\
\text { Mixes }\end{array}$ & Range of Alkalinity & Remarks \\
\hline Mix 1 & Colour less to purple & Moderate alkaline \\
\hline Mix 2 & Colour less to purple & Moderate alkaline \\
\hline Mix 3 & Colour less to violet red & Severe alkaline \\
\hline Mix 4 & $\begin{array}{c}\text { Colour less to light } \\
\text { purple }\end{array}$ & Mild alkaline \\
\hline
\end{tabular}

The alkalinity in concrete is increased after addition of mineral admixtures which will help in prevention of corrosion by providing passivity around the reinforcement

\section{CONCLUSION}

From the results of the present study, it may be concluded that the use of mineral admixtures in concrete showed that the compressive strength increased initially but percentage of admixtures is more than strength starts to decrease. The use of mineral admixtures in concrete makes the water absorption higher than the normal concrete. The split tensile strength using mineral admixtures is higher than normal concrete at 28 days. The cost of micro silica is high which intern increase the cost of concrete. Further studies are in progress to study the behaviour of high strength concrete when subjected to freezing and thawing. The combination of different mineral admixtures along with micro silica will be investigated. Different experimental studies programmed by keeping the percentage of fly ash as constant and vary the percentages of micro silica and quarry dust to check the strength of concrete.

\section{REFERENCES}

[1]. Pera, J. Amrouz, A. 2000. Development of highly reactive metakaolin from paper sludge. Advanced Cement Based Materials 7 (1), 49-56.

[2]. Tarun R.Naik, Thomas S. Friberg, Yoon-moon Chun. 2004. Use of pulp and paper mill residual solids in production of cellucrete, cement and concrete research, 34, 1229-1234.

[3]. T.R. Naik, R.N. Kraus. 2003. Use of residual solids from pulp and paper mills for enhancing strength and durability of ready-mixed concrete. US Dept. of Energy. DE-FC07 (00ID13867), 1-40.

[4]. Chun,Y., Kraus,R.N., 2005. Durable concrete through use of pulp and paper mill residuals, composites in construction In: Third international conference, July 11 - 13, Lyon, France. 6-9.

[5]. IS (Indian Standard) IS 10262-2009: Recommended Guidelines for Concrete Mix Design, Bureau of Indian Standards, New Delhi.

[6]. Naik, 2005. Concrete with paper industry fibrous residuals: mixture. ACI Materials Journal. 102 (4), 237-243.

[7]. Dehwaah H.A.F, 2012. Mechanical properties of self-compacting concrete incorporating quarry dust powder, silica fume or fly ash, Construction and Building Material, 26, 547-551.

[8]. Joseph O. Ukapata, and Godwin A. Akekee, 2012. Compressive strength of concrete using lateritic sand and quarry dust as fine aggregate, 7(1), 8192.

[9]. Mehmete Gesogalu, Erhana Güneyisi, and Dilere, 2015. Properties of low binder ultra-high performance cementitious composites: Comparison of nanosilica and microsilica. Construction and Building Material, 102 (2016) 706-713.

[10]. Srinivasan R., Sathiya K., and Palanisamy M. 2010. Experimental investigation in developing low cost concrete from paper industry waste. The Bulletin of the Polytechnic Institute of Jassy, Construction Architecture Section (Romania). 111 (3), 34-35.

[11]. Mudasira Hussain Pandita, Renuka Parameswari,D. 2014. High Density Concrete using fly ash, micro silica and recycled aggregate - an experimental study, IJETT -10 (1), 29-33.

[12]. IS (Indian Standard) IS 10262-2009: Recommended Guidelines for Concrete Mix Design, Bureau of Indian Standards, New Delhi. 